\title{
Рецидив пахової грижі: вплив супутньої патології
}

\begin{abstract}
Мета роботи: дослідити прямий вплив супутньої патології на ймовірність розвитку рецидиву пахової грижі.
Матеріали і методи. Проведено комплексне обстеження 31 пацієнта, які проходили стаціонарне лікування з приводу рецидивних пахових гриж (IV тип за L. M. Nyhus, 1993). Оскільки пахову грижу (K40 за MKX 10) переважно діагностують в осіб працездатного віку, для розподілу пацієнтів за віком використано класифікацію експертів ООН для соціально-економічних і демографічних розрахунків, а хворих віднесли до однієї з груп, відповідно: 15-24 роки - ранній працездатний вік (n=12); 25-54 роки - основний працездатний вік (n=19). Під час дослідження визначали терміни виникнення рецидиву пахової грижі, тип первинної герніопластики. Розподіл пацієнтів за типом супутньої патології здійснювали за МKX-10.

Результати досліджень та їх обговорення. Встановлено, що у пацієнтів вікової групи $\geq 25$ років виявлена супутня патологія за даними кореляційного аналізу не мала достовірного зв’язку з виникненням рецидиву. Натомість у пацієнтів вікової групи <25 років встановлено сильний позитивний зв'язок між такими супутніми захворюваннями, як варикозна хвороба вен нижніх кінцівок $(0,89)$, гастроезофагорефлюксна хвороба $(0,84)$, геморой $(0,91)$, синдром гіпермобільності суглобів $(0,78)$. Обгрунтуванням цих даних необхідно вважати системність ураження сполучної тканини в осіб молодого віку, які лежать в основі патологічних змін вище вказаних захворювань та зумовлюють високу частоту рецидивів та короткі терміни його виникнення після первинної герніопластики (до 5 років - 83,33 \%).
\end{abstract}

Ключові слова: пахова грижа; рецидив; супутня патологія; кореляція.

Постановка проблеми і аналіз останніх досліджень та публікацій. Незважаючи на значні хірургічні досягнення в герніології, результати операції з приводу пахової грижі залишаються неоднозначними. Одним із найчастіших ускладнень хірургічного лікування пахових гриж $є$ виникнення рецидиву [6], частота якого залежить від багатьох факторів: технічних нюансів попередньої хірургічної операції [2], індивідуальних особливостей організму хворого [5], перебігу післяопераційного періоду, при ігноруванні пацієнтом рекомендацій лікаря, що стосуються обмежень фізичного навантаження і режиму харчування $[1,3]$.

Ймовірність розвитку рецидиву пахових гриж підвищується при наявності у пацієнта супутніх захворювань, особливо синдрому недиференційованої дисплазії сполучної тканини $[4,7,8,11]$. Актуальність проблеми коморбідності у хірургічних хворих зумовлена тенденцією до збільшення кількості пацієнтів молодого віку з різними хронічними захворюваннями, підвищення негативного впливу факторів навколишнього середовища $[9,10]$.

Мета роботи: дослідити прямий вплив супутньої патології на ймовірність розвитку рецидиву пахової грижі.

Матеріали і методи. Проведено комплексне обстеження 31 пацієнта, які перебували стаціонарному лікуванні з приводу рецидивних пахових гриж (IV тип за L. M. Nyhus, 1993). Оскільки пахову грижу (K40 за MKX 10), переважно діагносту- ють в осіб працездатного віку, для розподілу пацієнтів за віком використано класифікацію експертів $\mathrm{OOH}$ для соціально-економічних і демографічних розрахунків, а хворих віднесли до однієї з груп, відповідно: 15-24 роки - ранній працездатний вік $(\mathrm{n}=12) ; 25-54$ років - основний працездатний вік $(\mathrm{n}=19)$. Під час дослідження визначали терміни виникнення рецидиву пахової грижі, тип первинної герніопластики. Розподіл пацієнтів за типом супутньої патології здійснювали за МКХ-10.

Статистичну оброку даних проводили із використанням варіаційного, кореляційного аналізу та викопіювання необхідної інформації із офіційної медичної документації (медична карта стаціонарного хворого, медична карта амбулаторного хворого). Обчислення результатів дослідження проводили на основі застосування стандартних програмних продуктів обробки інформації "Statistica".

Результати досліджень та їх обговорення. Відповідно до зібраного анамнезу та аналізу архівної медичної документації встановлено тип первинної герніопластики. У жодному випадку не було застосовано пластику з використанням сітчастого імпланту (табл. 1).

У всіх пацієнтів, які були включені в дослідження, на момент огляду було діагностовано тільки один рецидив пахової грижі (R1). Важливим показником був термін виникнення рецидиву (табл. 2). 
Таблиця 1. Розподіл пацієнтів за типом первинної герніопластики

\begin{tabular}{||c|c|c||}
\hline \multirow{2}{*}{ Тип первинної герніопластики } & \multicolumn{2}{|c||}{ Пацієнти з рецидивом } \\
\cline { 2 - 3 } & $<25$ років, $(\mathrm{n}=12)$ & $\geq 25$ років, (n=19) \\
\hline За Постемпським & $9(75,0 \%)$ & $15(78,95 \%)$ \\
\hline За Шолдайс & $2(16,67 \%)$ & $4(21,05 \%)$ \\
\hline За Бассіні & $1(8,33 \%)$ & - \\
\hline
\end{tabular}

Таблиця 2. Розподіл пацієнтів за терміном виникнення рецидиву

\begin{tabular}{||c|c|c||}
\hline \multirow{2}{*}{ Терміни виникнення рецидиву } & \multicolumn{2}{|c|}{ Пацієнти з рецидивом } \\
\cline { 2 - 3 } & $<25$ років, $(\mathrm{n}=12)$ & $\geq 25$ років, $(\mathrm{n}=19)$ \\
\hline$<5$ років & $10(83,33 \%)$ & $6(31,58 \%)$ \\
\hline $5-10$ років & $2(16,67 \%)$ & $11(57,89 \%)$ \\
\hline$>10$ років & - & $2(10,53 \%)$ \\
\hline
\end{tabular}

Із проведеного клініко-анамнестичного дослідження у пацієнтів із рецидивом встановлено структуру супутньої патології (табл. 3). Зауважимо, що дані захворювання були діагностовані за допомогою інструментальних методів дослідження під час попередніх госпіталізацій в профільні стаціонари (виписки зі стаціонарних карт) або 3 амбулаторних карт. Тобто всі дані були задокументовані профільними спеціалістами.

Для з’ясування прямої залежності від виявленої супутньої патології та рецидиву захворювання ми встановили кореляційні зв'язки. За допомогою кореляційного аналізу та розрахунку коефіцієнта кореляції встановлено характер та силу взаємозв’язку між виникненням рецидиву пахової грижі і наявністю у пацієнтів супутніх захворювань (табл. 4).

За даними таблиці 4 можна зробити висновок про наявність прямого зв’язку між виникненням рецидиву пахової грижі і наявністю супутніх захворювань. Кореляційний зв’язок характеризувався різною силою: слабкий, середній, сильний.

Таблиця 3. Розподіл пацієнтів за виявленою супутньою патологією (згідно з МКХ-10)

\begin{tabular}{|c|c|c|}
\hline \multirow{2}{*}{ Супутня патологія (MKX-10) } & \multicolumn{2}{|c|}{ Пацієнти з рецидивом } \\
\hline & $<25$ років, $(\mathrm{n}=12)$ & $\geq 25$ років, $(n=19)$ \\
\hline Хронічне обструктивне захворювання легень (J 44) & $1(8,33 \%)$ & $8(42,11 \%)$ \\
\hline Гіпертонічна хвороба (I 11.9) & $2(16,67 \%)$ & $9(47,37 \%)$ \\
\hline Ішемічна хвороба серця (I 20) & - & $11(57,89 \%)$ \\
\hline Порушення серцевого ритму (I 45.1, I 49.5, I 49.8, I49.9) & $7(58,33 \%)$ & $2(10,52 \%)$ \\
\hline Варикозна хвороба вен нижніх кінцівок (I 83.9) & $9(75,0 \%)$ & $2(10,52 \%)$ \\
\hline Геморой (I 84) & $10(83,33 \%)$ & $3(15,79 \%)$ \\
\hline Гастроезофагорефлюксна хвороба (К 21) & $8(66,67 \%)$ & $4(21,05 \%)$ \\
\hline Синдром подразненого кишечника (K 58) & $7(58,33 \%)$ & $5(26,32 \%)$ \\
\hline Синдром гіпермобільності суглобів (М 35.7) & $6(50,0 \%)$ & - \\
\hline
\end{tabular}


Таблиця 4. Взаємозв'язок рецидиву пахової грижі та наявністю супутньої патології (згідно з МКX-10)

\begin{tabular}{||l|c|c||}
\hline \multicolumn{1}{|c|}{ Супутня патологія (МКX-10) } & \multicolumn{2}{|c|}{ Коефіцієнт кореляції та сила взаємозв’язку } \\
\cline { 2 - 3 } & $<25$ років, (n=12) & $\geq 25$ років, (n=19) \\
\hline Хронічне обструктивне захворювання легень (J 44) & 0,06 & 0,15 \\
\hline Гіпертонічна хвороба (I 11.9) & 0,11 & 0,71 \\
\hline Ішемічна хвороба серця (I 20) & - & 0,83 \\
\hline Порушення серцевого ритму (I 45.1, I 49.5, I 49.8, I49.9) & 0,52 & 0,37 \\
\hline Варикозна хвороба вен нижніх кінцівок (I 83.9) & 0,89 & 0,74 \\
\hline Геморой (І 84) & 0,91 & 0,77 \\
\hline Гастроезофагорефлюксна хвороба (К 21) & 0,84 & 0,73 \\
\hline Синдром подразненого кишечника (К 58) & 0,62 & 0,49 \\
\hline Синдром гіпермобільності суглобів (М 35.7) & 0,78 & - \\
\hline \hline
\end{tabular}

Найвираженіший зв’язок спостерігали між рецидивами пахових гриж та наявністю у пацієнтів гастроезофагорефлюксної хвороби, варикозної хвороби та геморою. Зв'язок середньої сили був характерний для післяопераційних хворих із супутніми захворюваннями: серцеві аритмії та синдром подразненого кишечника.

Слабкий зв’язок спостерігали в пацієнтів із хронічними обструктивними захворюваннями легень та гіпертонічною хворобою (у молодому працездатному віці).

Висновок. Встановлено, що у пацієнтів вікової групи $\geq 25$ років виявлена супутня патологія за даними кореляційного аналізу не мала достовірного зв’язку 3 виникненням рецидиву.

Натомість у пацієнтів вікової групи $<25$ років встановлено сильний позитивний зв'язок між такими супутніми захворюваннями, як варикозна хвороба вен нижніх кінцівок $(0,89)$, гастроезофагорефлюксна хвороба $(0,84)$, геморой $(0,91)$, синдром гіпермобільності суглобів $(0,78)$. Обгрунтуванням цих даних необхідно вважати системність ураження сполучної тканини в осіб молодого віку, які лежать в основі патологічних змін вищевказаних захворювань та зумовлюють високу частоту рецидивів та короткі терміни його виникнення після первинної герніопластики (до 5 років - 83,33%).

\section{СПИСОК ЛІТЕРАТУРИ}

1. Causes of recurrences after open inguinal herniorrhaphy / D. Ashrafi, M. Siddaiah-Subramanya, B. Memon, M. A. Memon // Hernia. - 2019. - Vol. 23 (4). - P. 637-645.

2. Bittner R. Inguinal hernia repair: current surgical techniques / R. Bittner, J. Schwarz // Langenbeck's Archives of Surgery. 2012. - Vol. 397 (2). - P. 271-282.

3. Patient-related risk factors for recurrence after inguinal hernia repair: a systematic review and meta-analysis of observational studies / J. Burcharth, H. C. Pommergaard, T. Bisgaard, J. Rosenberg // Surgical Innovation. - 2015. - Vol. 22 (3). - P. 303-317.

4. Hernia recurrence as a problem of biology and collagen / U. Klinge, M. Binnebösel, R. Rosch, P. Mertens // Journal of Minimal Access Surgery. - 2006. - Vol. 2 (3). - P. 151.

5. Anatomical changes after inguinal hernia treatment: a reason for chronic pain and recurrent hernia? / R. Kocijan, S. Sandberg, Y. W. Chan, C. Hollinsky // Surgical Endoscopy. 2010. - Vol. 24 (2). - P. 395-399.

6. Melkemichel M. Long-term comparison of recurrence

rates between different lightweight and heavyweight meshes in open anterior mesh inguinal hernia repair: a nationwide population-based register study / M. Melkemichel, S. A. W. Bringman, B. O. O. Widhe // Annals of Surgery. - 2021. - Vol. 273 (2). P. 365-372.

7. Дженг Ш. Дисплазия соединительной ткани как причина развития рецидива паховой грыжи (с комментарием) / Ш. Дженг, С. Р. Добровольский // Хирургия. Журнал им. Н. И. Пирогова. - 2014. - № 9. - С. 61-63.

8. Дзюбановский И. Я. Клинико-диагностические критерии дисфункции соединительной ткани у больных варикозной болезнью вен нижних конечностей / И. Я. Дзюбановский, А. М. Продан // Хирург. - 2016. - № 3. - С. 36-41.

9. Хабибулина М. М. Безболевая ишемия миокарда у молодых женщин с кардиалгией, дисгормонозом и разной коморбидностью (сердечной и внесердечной) / М. М. Хабибулина, М. Д. Шамилов // Doctor. - 2016. - № 32(3). - C. 61-65.

10. Хидирова Л. Д. Прогрессирование фибрилляции пред- 
сердий у коморбидных больных среднего возраста / Л. Д. Хидирова, Д. А. Яхонтов, В. Л. Лукинов // Международный журнал сердца и сосудистых заболеваний. - 2021. - № 9 (30). - С. 43-52.

\section{REFERENCES}

1. Ashrafi, D., Siddaiah-Subramanya, M., Memon, B., \& Memon, M. A. (2019). Causes of recurrences after open inguinal herniorrhaphy. Hernia, 23 (4), 637-645.

2. Bittner, R., \& Schwarz, J. (2012). Inguinal hernia repair: current surgical techniques. Langenbeck's Archives of Surgery, 397 (2), 271-282.

3. Burcharth, J., Pommergaard, H. C., Bisgaard, T., \& Rosenberg, J. (2015). Patient-related risk factors for recurrence after inguinal hernia repair: a systematic review and meta-analysis of observational studies. Surgical Innovation, 22 (3), 303-317.

4. Klinge, U., Binnebösel, M., Rosch, R., \& Mertens, P. (2006). Hernia recurrence as a problem of biology and collagen. Journal of Minimal Access Surgery, 2 (3), 151.

5. Kocijan, R., Sandberg, S., Chan, Y. W., \& Hollinsky, C. (2010). Anatomical changes after inguinal hernia treatment: a reason for chronic pain and recurrent hernia? Surgical Endoscopy, 24 (2), 395-399.

6. Melkemichel, M., Bringman, S.A.W., \& Widhe, B.O.O. (2021). Long-term comparison of recurrence rates between different lightweight and heavyweight meshes in open anterior mesh inguinal hernia repair: a nationwide population-based register study. Annals of Surgery, 273 (2), 365-372.

7. Djeng, S.H., \& Dobrovolskiy, S.R. (2014). Displaziya soedinitelnoy tkani kak prichina razvitiya retsidiva pahovoy gryzhi (s kommentariem) [Dysplasia of connective tissue as a cause of recurrent inguinal hernia (with commentary)]. Hirurgiya. Zhurnal
11. Результаты лечения паховых грыж у пацентов с синдромом дисплазии соединительной ткани / Ю. А. Черепанова, А. Я. Мальчиков // Хирургическая практика. - 2016. - № 2. - C. 11-13. im. N.I. Pirogova - Surgery. Journal named after N.I. Pirogov, (9), 61-63 [in Russian].

8. Dzyubanovskiy, I. Ya., \& Prodan, A.M. (2016). Kliniko-diagnosticheskie kriterii disfunktsii soedinitelnoy tkani u bolnykh varikoznoy boleznyu ven nizhnikh konechnostey [Clinical and diagnostic criteria for connective tissue dysfunction in patients with varicose veins of the lower extremities]. Hirurg - Surgeon, (3), 36-41 [in Russian].

9. Habibulina, M.M., \& Shamilov, M.D. (2021). Bezbolevaya ishemiya miokarda u molodykh zhenshchin s kardialgiey, disgormonozom i raznoy komorbidnostyu (serdechnoy i vneserdechnoy) [Painless myocardial ischemia in young women with cardialgia, dyshormonosis and various comorbidity (cardiac and extracardiac)]. Doctor, 32 (3), 61-65 [in Russian].

10. Hidirova, L.D., Yahontov, D.A., \& Lukinov, V.L. (2021). Progressirovanie fibrillyatsii predserdiy u komorbidnyh bolnyh srednego vozrasta [Progression of atrial fibrillation in middle-aged comorbid patients]. Mezhdunarodnyy zhurnal serdtsa i sosudistykh zabolevaniy - International Journal of Heart and Vascular Diseases, 9 (30), 43-52 [in Russian].

11. Cherepanova, Yu.A., \& Malchikov, A.Ya. (2016). Rezultaty lecheniya pahovyh gryzh u patsentov s sindromom displazii soedinitelnoy tkani [Results of treatment of inguinal hernias in patients with connective tissue dysplasia syndrome]. Hirurgicheskaya praktika - Surgical Practice, (2), 11-13 [in Russian].

Отримано 17.06.2021

Електронна адреса для листування: prodan@tdmu.edu.ua

\author{
V. V. BENEDYKT, A. M. PRODAN, L. M. ROMANJUK
}

I. Horbachevsky Ternopil National Medical University

\title{
RECURRENT INGUINAL HERNIA: THE EFFECT OF CONCOMITANT PATHOLOGY
}

The aim of the work: to investigate the direct impact of comorbidities on the likelihood of recurrence of inguinal hernia. Materials and Methods. A comprehensive examination of 31 patients who had undergone inpatient treatment for recurrence inguinal hernias was conducted (type IV by L.M. Nyhus, 1993). Thus, as inguinal hernia (K40 according to ICD-10), was mainly found in people of working age to classify patients by age used the classification of UN experts for socio-economic and demographic calculations, and people were assigned to one of the groups, respectively: 15-24 years - early working age ( $n=12$ ); 25-54 years - the main working age $(n=19)$. During the current study, the timing of recurrence of inguinal hernia, the type of primary hernioplasty were determined. The distribution of patients by type of comorbidity was carried out according to ICD-10.

Results and Discussion. In patients aged $\geq 25$ years, concomitant pathology was found to be unrelated to recurrence of inguinal hernia based on correlation analysis. In contrast, in patients aged $<25$ years, a strong positive association was found between comorbidities such as varicose veins of the lower extremities (0.89), gastroesophageal reflux disease (0.84), hemorrhoids (0.91), and joint hypermobility syndrome (0.78). The substantiation of these data should be considered the systemic connective tissue lesions in young people, which underlie the pathological changes of the above diseases and cause a high recurrence rate and short duration of its occurrence after primary hernioplasty (up to 5 years $-83.33 \%$ ).

Key words: inguinal hernia; recurrence; concomitant pathology; correlation. 